\title{
Perancangan Data Warehouse untuk Profiling Data Pelanggan pada Bidang Telekomunikasi
}

\author{
Rokhmatul Insani ${ }^{1)}$ \\ ${ }^{1)}$ Sistem Informasi, Fakultas Teknologi Industri dan Bisnis, Institut Teknologi Telkom Surabaya \\ Jalan Ketintang No.156, Surabaya, 60231, Indonesia \\ Email: insani@ittelkom-sby.ac.id ${ }^{1)}$
}

\begin{abstract}
Abstrak
Pelanggan merupakan aset terpenting pada sebuah perusahaan, termasuk pada perusahaan pada bidang telekomunikasi. Banyaknya data pelanggan dapat dimanfaatkan untuk mencari informasi lebih detail mengenai pelanggan sehingga dapat memberikan pelayanan terbaik bagi pelanggan. Profil pelanggan dapat membantu perusahaan untuk lebih memahami basis pelanggan yang dimiliki. Profil pelanggan diperlukan perusahaan untuk mengetahui karakteristik pelanggan sehingga mempermudah perusahaan melakukan pemasaran terhadap para pelanggan tersebut. Profil pelanggan dapat dilakukan dengan intelijen bisnis. Salah satu komponen intelijen bisnis adalah data warehouse. Data warehouse digunakan untuk menyimpan data secara historis yang berasal dari data transaksional. Penelitian ini menghasilkan skema data warehouse sesuai dengan kebutuhan bisnis perusahaan.
\end{abstract}

Kata kunci: Data Warehouse, Profil Pelanggan, Perusahaan Telekomunikasi

\section{Pendahuluan (Introduction)}

Pelanggan merupakan aset utama dalam sebuah perusahaan. Cara mengelola pelanggan dengan baik menjadi faktor penting guna memenangkan persaingan bisnis, termasuk dalam bidang Telekomunikasi. Profiling data pelanggan diperlukan oleh perusahaan untuk mempermudah perusahaan dalam memberikan gambaran mengenai karakteristik para pelanggannya juga dapat memberikan penawaran pada pelanggan sesuai dengan karakteristiknya sehingga penawaran tersebut tepat sasaran. Tantangannya adalah bagaimana dengan teknologi dapat menjawab besar dan kompleksnya data yang ada. Salah satu solusinya adalah dengan menerapkan intelijen bisnis.

Menurut Gartner, Intelijen Bisnis (bahasa Inggris: Business Intelligence, BI) merupakan seperangkat aplikasi, infrastruktur dan alat, dan metode yang digunakan dalam mengakses dan menganalisis informasi untuk tujuan optimalisasi keputusan dan performansi. BI dapat melakukan ekstrasi pola dari data sehingga dapat ditemukan informasi yang berguna bagi perusahaan. Dengan BI dapat digunakan untuk membantu perusahaan untuk menggambarkan histori bisnis perusahaan, melihat kondisi perusahaan saat ini, dan memprediksi kondisi yang akan datang (Gartner, 2015).

Untuk memberikan sudut pandang bisnis secara historis, data dikumpulkan dalam suatu gudang data, gudang data tersebut bersumber pada data operasional. Selanjutnya dari gudang data (data warehouse) dapat dilakukan analisis lebih lanjut (Almeida, 2017). Gambaran intelijen bisnis dapat dilihat pada gambar 1 berikut. 


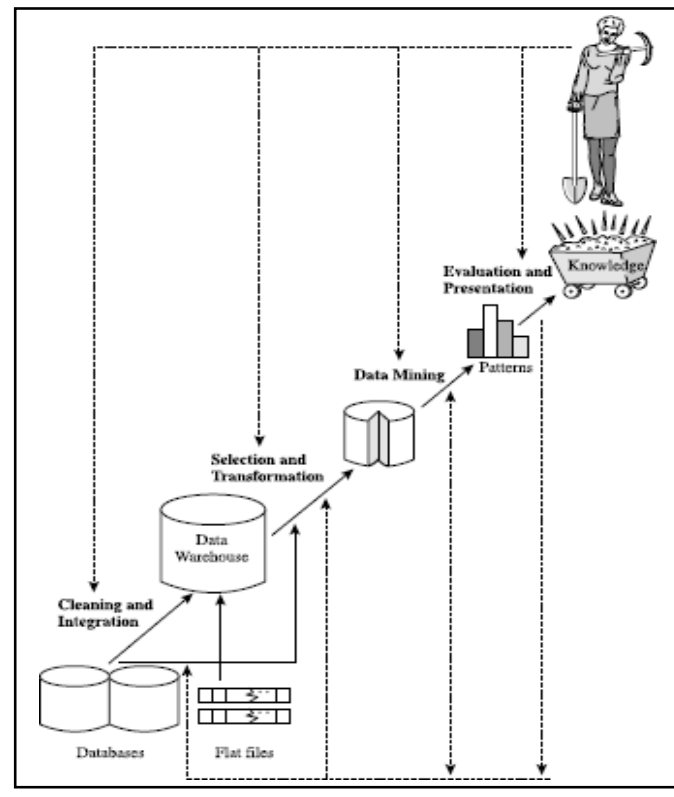

Gambar 1. Gambaran Intelijen Bisnis

Berdasarkan penjabaran diatas, pada penelitian ini akan dilakukan penerapan intelijen bisnis dengan menggunakan data riil pada suatu perusahaan telekomunikasi di Indonesia. Dimana pada perusahaan tersebut memiliki beberapa layanan yaitu layanan telepon, internet dan tv kabel. Untuk kebutuhan profiling data pelanggan, data yang akan digunakan adalah: data pelanggan beserta data paket produk yang digunakan, data pemakaian layanan, data tagihan pelanggan dan data pembayaran pelanggan.

Pada penelitian ini akan dirancang skema penyimpanan data dalam bentuk data warehouse. Data warehouse yang akan dibangun berdasarkan proses bisnis yang terjadi pada perusahaan serta data transaksional yang dimiliki oleh perusahaan tersebut. Selain itu, adanya data warehouse juga memperlihatkan kondisi saat ini, serta masa lampau. Sehingga didapatkan gambaran apakah perusahaan mengalami peningkatan atau sebaliknya.

\section{Metode Penelitian (Methods)}

Dalam pembangunan data warehouse terdapat dua pendekatan yang saling bertentangan yang dikemukanan oleh Inmon dan Kimball. Inmon menggunakan metode top-down sedangkan Kimball menggunakan metode bottom-up. Pada pendekatan Top-Down, data warehouse dipandang sebagai pusat lingkungan analisis (Hofer, 2016). Data warehouse menyimpan data transaksi yang atomik yang diekstrak dari satu atau beberapa sumber dan diintegrasikan dalam enterprise data model yang dinormalisasikan (Inmon, 2005). Sedangkan pada pendekatan Bottom-Up atau disebut juga data warehouse bus architeture, Arsitektur inimenggunakan independen data mart (Kimball R. M., 2002). Data mart yang terpisah ini bisa digabungkan apabila dibuat berdasarkan standar.

Metode top-down merupakan metode dimana kita harus mengetahui seluruh proses bisnis yang berlaku pada perusahaan, kemudian dilakukan pembangunan data warehouse secara keseluruhan, sehingga skema yang dihasilkan akan nampak kompleks. Keuntungannya adalah didapatkan gambaran yang utuh mengenai semua proses bisnis perusahaan tersebut, namun diperlukan waktu yang lama dalam pengerjaan (Suba, 2018).

Pada pendekatan bottom-up oleh Kimball data warehouse dibangun berdasarkan proses bisnis tunggal pada perusahaan, misalnya pembangunan data warehouse pada proses bisnis tagihan dan pembayaran digambarkan terpisah, layaknya sebuah puzzle untuk menggabungkan semua proses bisnis tersebut diperlukan sebuah blue print arsitektur untuk melihat secara keseluruhan yang disebut dengan bus architecture (Dageville, 2016). Keunggulan pada pendekatan ini adalah fleksibelitas, lebih mudah untuk diimplementasikan, serta desain yang dihasilkan lebih sederhana dan mudah dimengerti.

Dengan mempertimbangkan kedua pendekatan diatas, maka dalam penelitian ini akan digunakan pendekatan bottom-up dari Kimball. Pendekatan ini dipilih karena pada penelitian kali ini hanya melibatkan beberapa proses bisnis pada perusahaan tersebut. 
Tahapan perancangan data warehouse dengan metode kimball yang dilakukan pada penelitian ini adalah sebagai berikut (Kimball R. M., 2007):

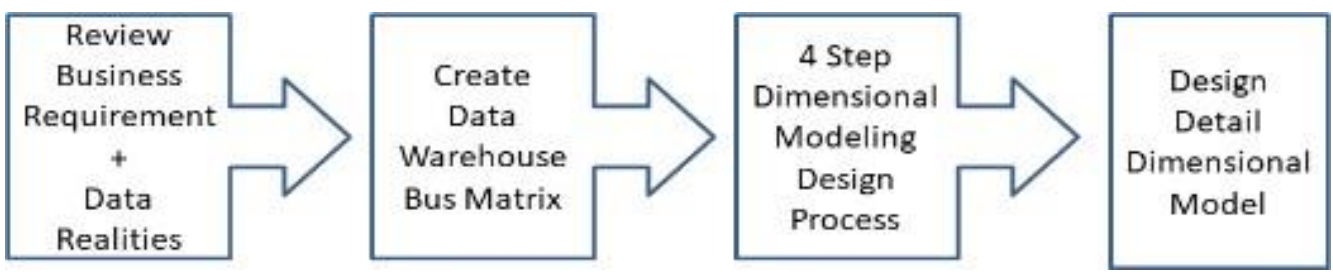

Gambar 2. Tahapan perancangan data warehouse

Pada tahapan ke 3 mengenai proses pemodelan dimensional dapat diuraikan dengan beberapa Langkah, yaitu:

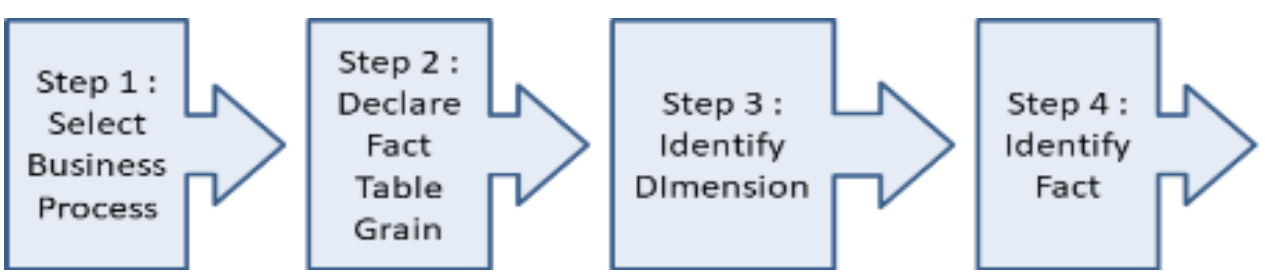

Gambar 3. Proses Pemodelan Dimensional

\section{Hasil dan Pembahasan (Results and Discussions)}

Berdasarkan pendekatan top-down, maka perancangan data warehouse untuk perusahaan telekomunikasi sebagai berikut:

\subsection{Rincian Kebutuhan Bisnis}

Kebutuhan bisnis didapatkan dengan melakukan wawancara dengan pihak perusahaan, berikut rinciannya:

1. Profiling data pelanggan harus dapat mencatat semua proses bisnis yang terjadi pada perusahaan Telekomunikasi X.

2. Dapat melihat data detail mengenai identitas pelanggan, layanan yang dipakai pelanggan maupun jumlah pemakaian layanan.

3. Dapat melihat jumlah pelanggan per daerah, per kota, per provinsi dan per regional.

4. Dapat melihat jumlah layanan yang dimiliki per pelanggan per daerah, per kota, per provinsi dan per regional.

5. Dapat melihat total pemakaian tiap layanan (telepon, internet, TV kabel) per pelanggan, per daerah, per kota, per provinsi dan per regional.

6. Dapat melihat tagihan layanan per bulan per pelanggan, per daerah, per kota, per provinsi dan per regional.

7. Dapat melihat pembayaran layanan per bulan per pelanggan, per daerah, per kota, per provinsi dan per regional.

8. Dapat melihat tren pemakaian untuk setiap layanan (telephone, internet, TV kabel) per pelanggan per daerah, per kota, per provinsi dan per regional.

Data transaksional yang dimiliki perusahaan merupakan data terstruktur, data diambil dari beberapa database yang menyimpan proses transaksi. 


\subsection{Bus Matrix Data Warehouse}

Berdasarkan identifikasi kebutuhan di atas, serta dengan menganalisis proses bisnis, selanjutnya akan dirancang bus matrix. Bus matrix menggambarkan pemetaan kandidat tabel fakta dan tabel dimensi. Bus matrix merupakan blue print perancangan skema data warehouse (Das, 2019). Setelah kita menjabarkan mengenai kebutuhan bisnis oleh user pada poin 3.1 maka secara garis besar yang akan akan diukur performansi bisnisnya mengenai pemakaian layanan oleh pelanggan, tagihan dan pembayaran (Nasrullah, 2021). Pemakaian layanan sendiri terdiri dari 3 yaitu pemakaian telepon, internet dan TV kabel, masing-masing memiliki karakteristik pengukuran performansi yang berbeda. Jadi pada studi kasus ini yang akan menjadi kandidat tabel fakta adalah pemakaian telepon, pemakaian internet, pemakaian TV kabel, tagihan pelanggan dan pemakaian pelanggan.

Dalam penentuan tabel dimensi, dapat digunakan kamus data. Prosesnya adalah menentukan tabel apa saja yang akan dijadikan sebagai sumber kemudian ditentukan konteks apa saja yang mewakili setiap data pada tabel tersebut. Misalnya pada setiap baris data tagihan pelanggan akan dicatat mengenai tanggal tagihan beserta data pelanggan, sehingga yang akan menjadi kandidat tabel dimensi adalah data waktu dan data pelanggan. Berdasarkan penjelasan diatas maka bus matrix pada studi kasus ini dapat dilihat pada gambar 3 .

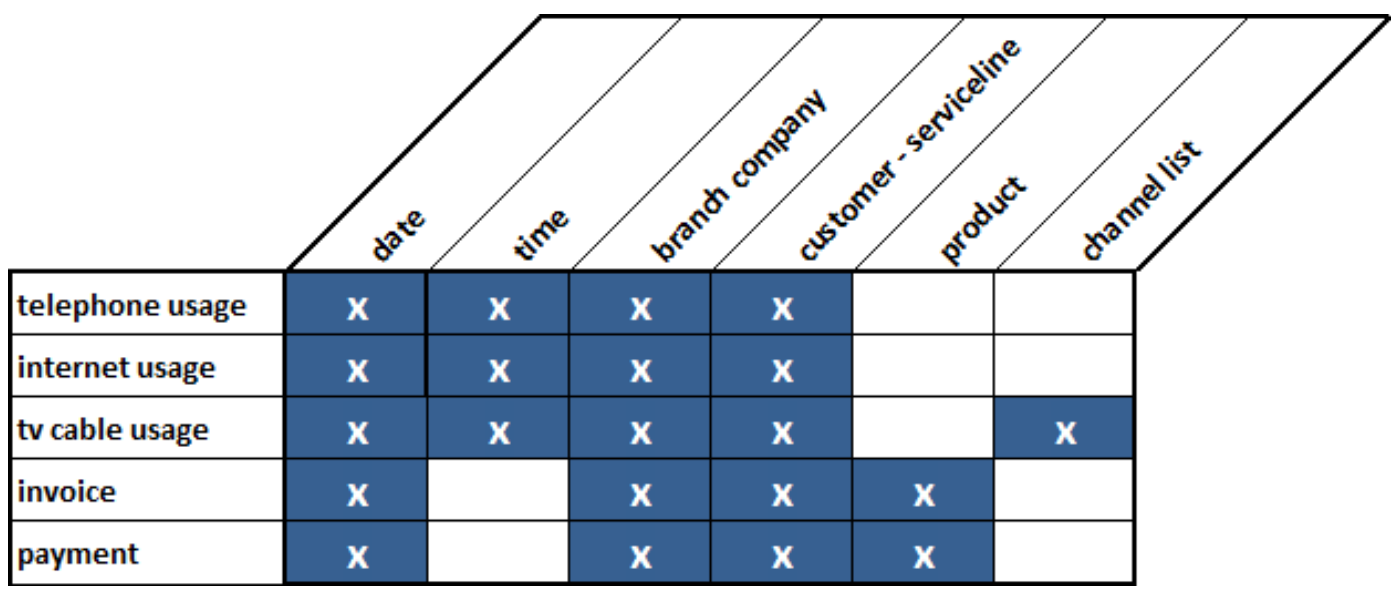

Gambar 4 Bus Matrix Data Warehouse untuk Profiling Data Pelanggan pada Perusahaan Telekomunikasi

Gambar 4 menggambarkan kandidat tabel fakta pada sisi kiri dan kandidat tabel dimensi pada sisi atas. Tanda $\mathrm{X}$ berarti fact table berhubungan dengan dimensi tersebut.

\subsection{Pemodelan Dimensional}

\subsubsection{Proses Bisnis Perusahaan}

Proses Bisnis pada perusahaan telekomuikasi dapat digambarkan dalam bentuk flowchart seperti pada gambar berikut : 


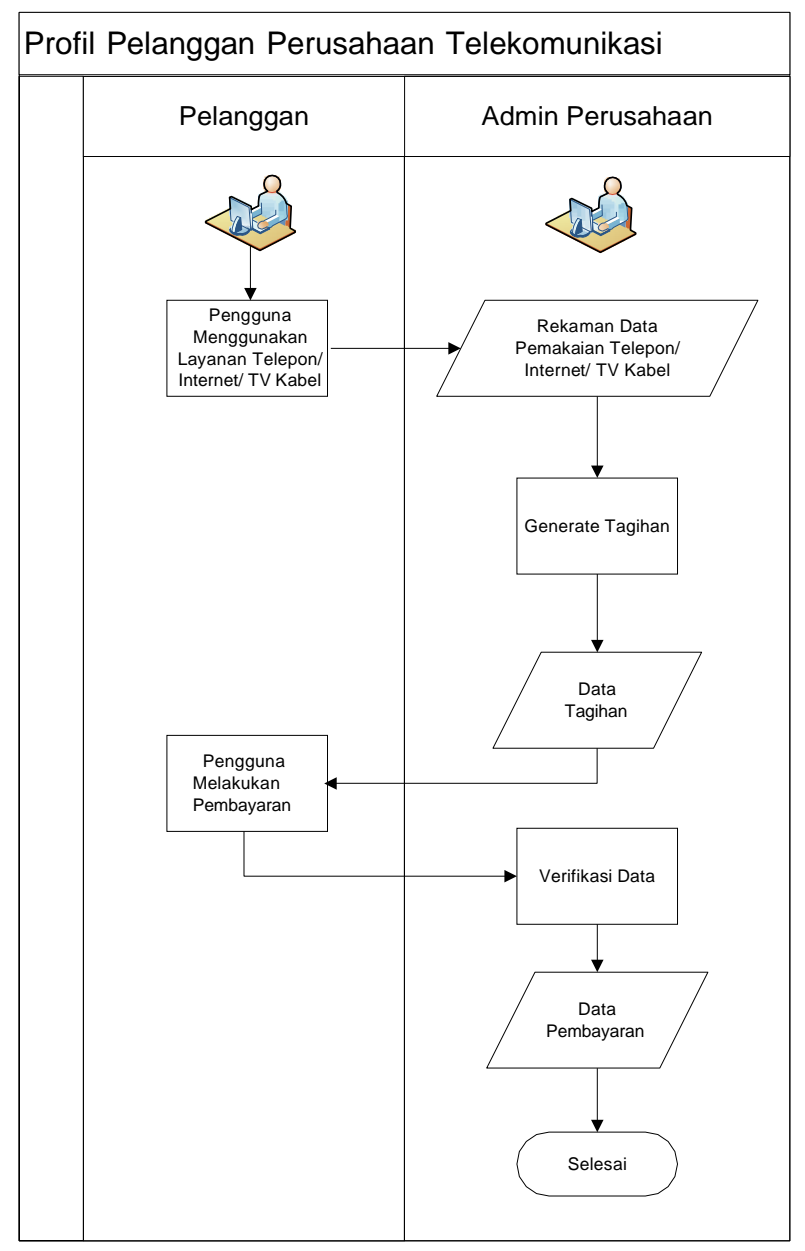

Gambar 5 Flowchart Proses Bisnis Pembayaran Penggunaan Layanan pada Perusahaan Telekomunikasi

Gambaran bisnis secara lebih rinci dapat dijabarkan sebagai berikut :

- Perusahaan telekomunikasi X memiliki cabang diseluruh wilayah Indonesia yang dibagi per regional, kota dan per area.

- Perusahaan telekomunikasi X memiliki 3 layanan utama yaitu layanan telepon, layanan internet dan layanan tv kabel.

- Perusahaan telekomunikasi X memiliki banyak paket produk dengan tarif bervariasi yang ditawarkan kepada pelanggan untuk setiap layanannya. Misalnya untuk lanyanan internet tersedia paket INET3GB, INET6GB, dst.

- Setiap pelanggan bisa memasang layanan lebih dari 1. Misalnya 1 pelanggan memiliki 2 rumah dimana setiap rumah memasang layanan telepon dan internet.

- Pemakaian telepon dibedakan menjadi beberapa tipe yaitu pemakaian telepon lokal, interlokal, internasional, dst. Untuk pemakaian telepon akan tercatat nomor tujuan, waktu panggilan, durasi panggilan, kode kota ataupun kode negara dan nomor imei device.

- Pada pemakaian internet tercatat waktu awal dan akhir pemakaian beserta besarnya pemakaian internet tersebut.

- Pada pemakaian tv kabel tercatat waktu awal dan akhir pemakaian berdasarkan channel yang dilihat. Data channel meliputi nama channel dan jenis paket tv kabel.

- Tagihan pelanggan digenerate pada tanggal tertentu dan mempunyai batas waktu tertentu, tagihan berdasarkan layanan yang digunakan juga meliputi tagihan penginstallan jaringan, denda, pajak, biaya garansi, biaya pemasangan nomor spesial yang sesuai permintaan pelanggan, biaya panggilan lokal, interlokal, internasional, dan biaya lainnya. 
- Tagihan yang digenerate juga dihitung tunggakan pembayaran sebelumnya dimana tunggakan merupakan jumlah pembayaran dikurang jumlah tagihan.

- Pembayaran dilakukan per layanan yang ada, tercatat tanggal pembayaran dan tanggal jatuh tempo yang diberikan. Tersimpan juga data pembayaran yaitu bank tempat pembayaran, channel yang digunaan, besar pembayaran nomor tagihan.

\subsubsection{Mendeskripsikan Tingkat Kedetailan Tabel fakta}

Tingkat kedetailan untuk masing-masing proses bisnis yang terlibat dalam perancangan data warehouse:

a. Pada proses bisnis pemakaian telephone, meliputi:

- Pemakaian telephone dilakukan oleh pelanggan aktif pada perusahaan X yang dilayani oleh cabang tertentu.

- Pemakaian telephone dihitung berdasarkan durasi lamanya pemakaian telephone.

- Pemakaian telephone dapat dibagi berdasarkan tipe panggilan, seperti lokal, interlokal dan internasional.

- Tercatat tanggal dan waktu pemakaian awal dan akhir layanan telephone.

b. Pada proses bisnis pemakaian internet, meliputi:

- Pemakaian internet dilakukan oleh pelanggan aktif pada perusahaan X yang dilayani oleh cabang tertentu.

- Pemakaian internet dihitung berdasarkan durasi lamanya pemakaian internet, banyaknya pemakaian internet (byte send dan byte receive).

- Tercatat tanggal dan waktu pemakaian awal dan akhir layanan telephone.

c. Pada proses bisnis pemakaian TV kabel, meliputi:

- Pemakaian tv kabel dilakukan oleh pelanggan aktif pada perusahaan X yang dilayani oleh cabang tertentu.

- Terdapat beberapa channel TV yang disajikan untuk pelanggan.

- Pemakaian TV kabel dihitung berdasarkan durasi lamanya pemakaian per channel yang ditonton.

- Tercatat tanggal dan waktu pemakaian awal dan akhir layanan tv cable.

d. Pada proses bisnis generate tagihan, meliputi:

- Setiap bulannya perusahaan akan melakukan generate tagihan dari para pelanggannya.

- Tagihan digenerate per layanan yang dipakai oleh pelanggannya.

- Terdapat rincian data tagihan.

e. Pada proses bisnis pembayaran, meliputi:

- Setiap bulannya pelanggan harus melakukan pembayaran atas pemakaian layanan yang digunakannya.

- Besarnya pembayaran berdasarkan tagihan yang telah digenerate oleh perusahaan.

- Tercatat tanggal pembayaran oleh pelanggan.

\subsubsection{Mengidentifikasi Dimensi}

Tahapan berikutnya dengan mengidentifikasikan dimensi yang sesuai dengan tabel fakta bedasarkan tingkat kedetailan yang telah di deskripsikan sebelumnya serta dari bus matrix yang telah dibuat sebelumnya, maka pada penelitian ini melibatkan beberapa dimensi, yaitu :

Tabel 1. Identifikasi Dimensi

\begin{tabular}{|l|l|l|}
\hline Nama Dimensi Asal & Nama Dimensi di Skema & \multicolumn{1}{|c|}{ Tipe Dimensi } \\
\hline Dimensi Pelanggan & Dim_Customer_Serviceline & conformed dimension \\
\hline $\begin{array}{l}\text { Dimensi Cabang } \\
\text { Perusahaan }\end{array}$ & Dim_branch_company & conformed dimension \\
\hline Dimensi Tanggal & Dim_date & role play dimension \\
\hline Dimensi Waktu & Dim_time & role play dimension \\
\hline $\begin{array}{l}\text { Dimensi Channel } \\
\text { List }\end{array}$ & Dim_channel_list & single dimension \\
\hline
\end{tabular}




\begin{tabular}{|l|l|l|}
\hline $\begin{array}{l}\text { Dimensi Tipe } \\
\text { Panggilan }\end{array}$ & Dim_calling_type & single dimension \\
\hline Dimensi Produk & Dim_product_services & conformed dimension \\
\hline
\end{tabular}

\subsubsection{Mengidentifikasi Fakta}

Tahapan akhir dalam pemodelan dimensional adalah mengidentifikasikan fakta atau pegukuran (measures) dari proses bisnis yang ada. Dari proses bisnis yang akan digunakan maka didapatkan 5 tabel fakta yaitu pemakaian layanan telephone, pemakaian layanan internet, pemakaian layanan tv kabel, tagihan dan pembayaran. Untuk masing-masing variable pengukuran pada tabel fakta, meliputi:

a) Fact Pemakaian Telephone, meliputi:

- Durasi pemakaian telephone.

b) Fact Pemakaian Internet, meliputi:

- Durasi pemakaian internet.

- Byte sent / upload.

- Byte receive / download.

c) Fact Pemakaian TV kabel, meliputi:

- Durasi pemakaian TV kabel.

d) Fact Tagihan, meliputi:

- Total tagihan.

e) Fact Pembayaran, meliputi:

- Total pembayaran.

\subsection{Perancangan Skema Data Warehouse}

Tahap terakhir pada penelitian ini adalah merancang skema data warehouse, yang didasarkan pada bus matrix yang telah dibuat. Dari bus matix dapat diperoleh 5 skema yang masing-masing akan mewakili proses bisnis yang berlaku pada perusahaan tersebut.

Terdapat dua jenis skema dalam data warehouse yaitu star schema dan snowflake schema. Star schema terdiri dari satu tabel fakta dan sejumlah tabel dimensi yang terkait dengan tabel fakta. Snowflake schema memiliki struktur yang lebih kompleks dari pada star schema. Dalam snowflake schema, dilakukan normalisasi untuk menghilangkan redundansi, tabel dimensi dikelompokkan menjadi beberapa tabel. Pemodelan dimensi tidak hanya berdasarkan pada proses bisnis, tetapi juga berdasarkan pada data transaksional yang ada (Farooqui, 2018). Berdasarkan bus matriks, terdaapat 5 skema yang menggunakan starschema. Kelima skema data warehouse tersebut adalah: 


\section{Skema Pemakaian Telepon}

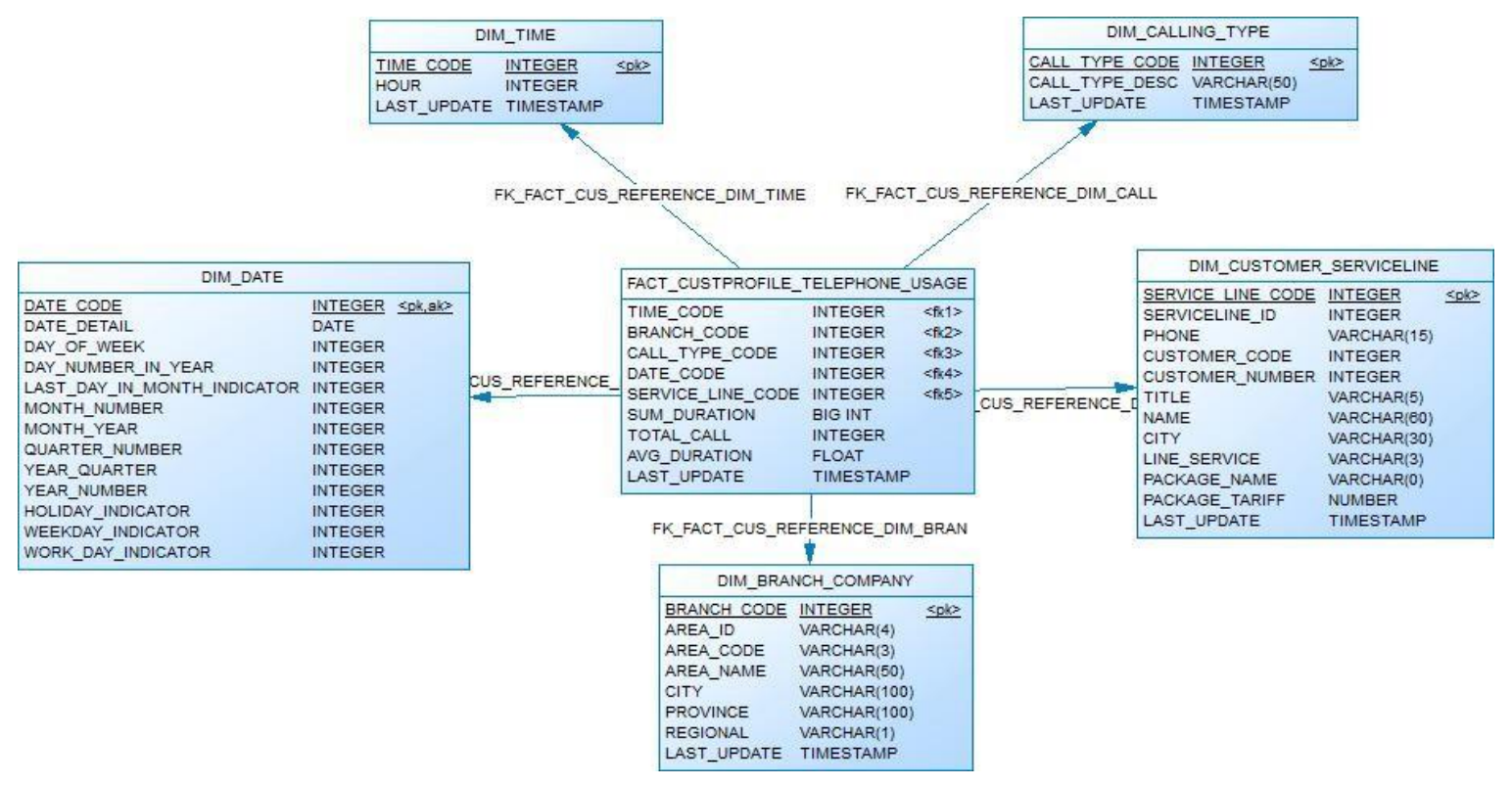

Gambar 6 Skema Telephone Usage

\section{Skema Pemakaian Internet}

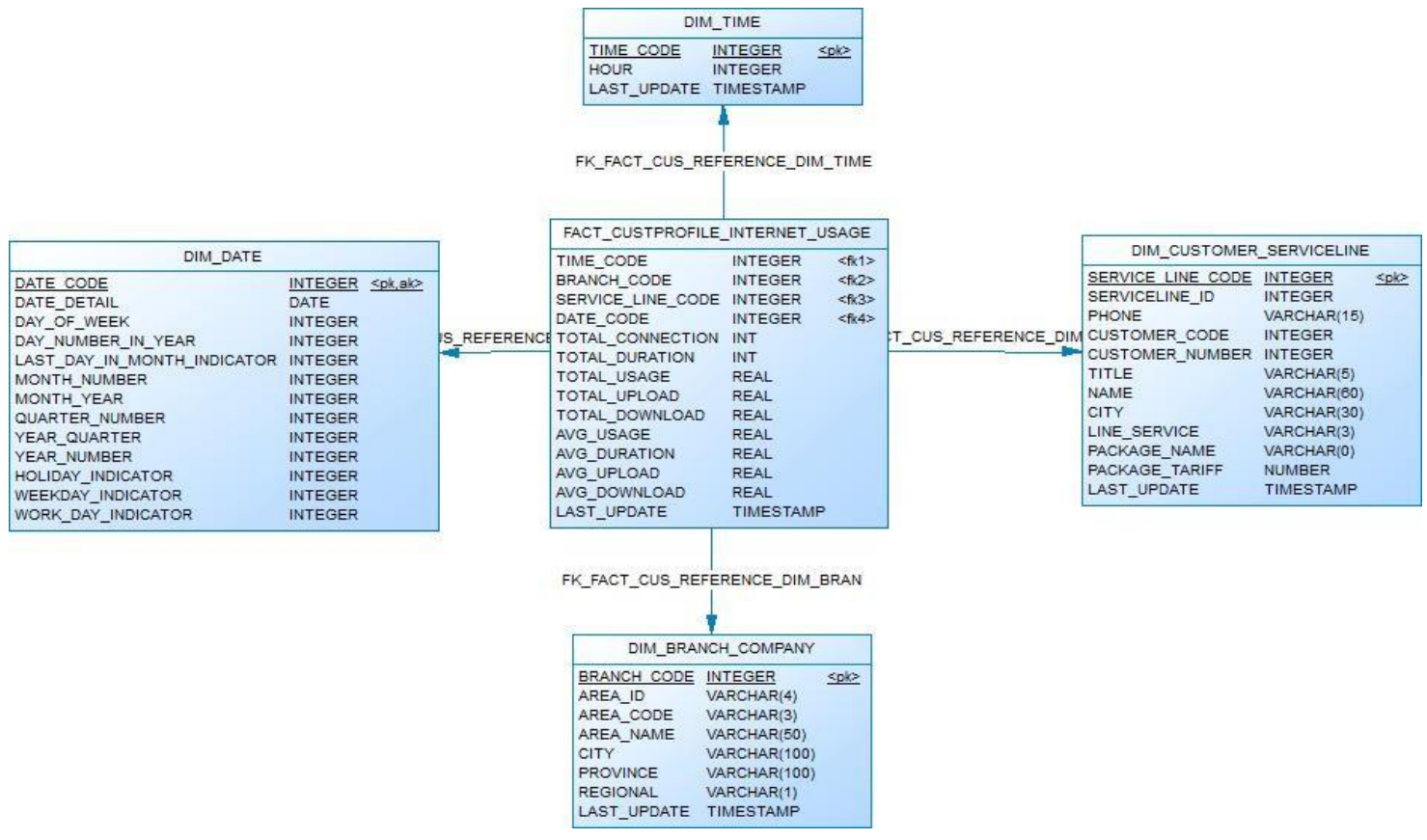

Gambar 7 Skema Internet Usage 


\section{Skema Pemakaian TV Kabel}

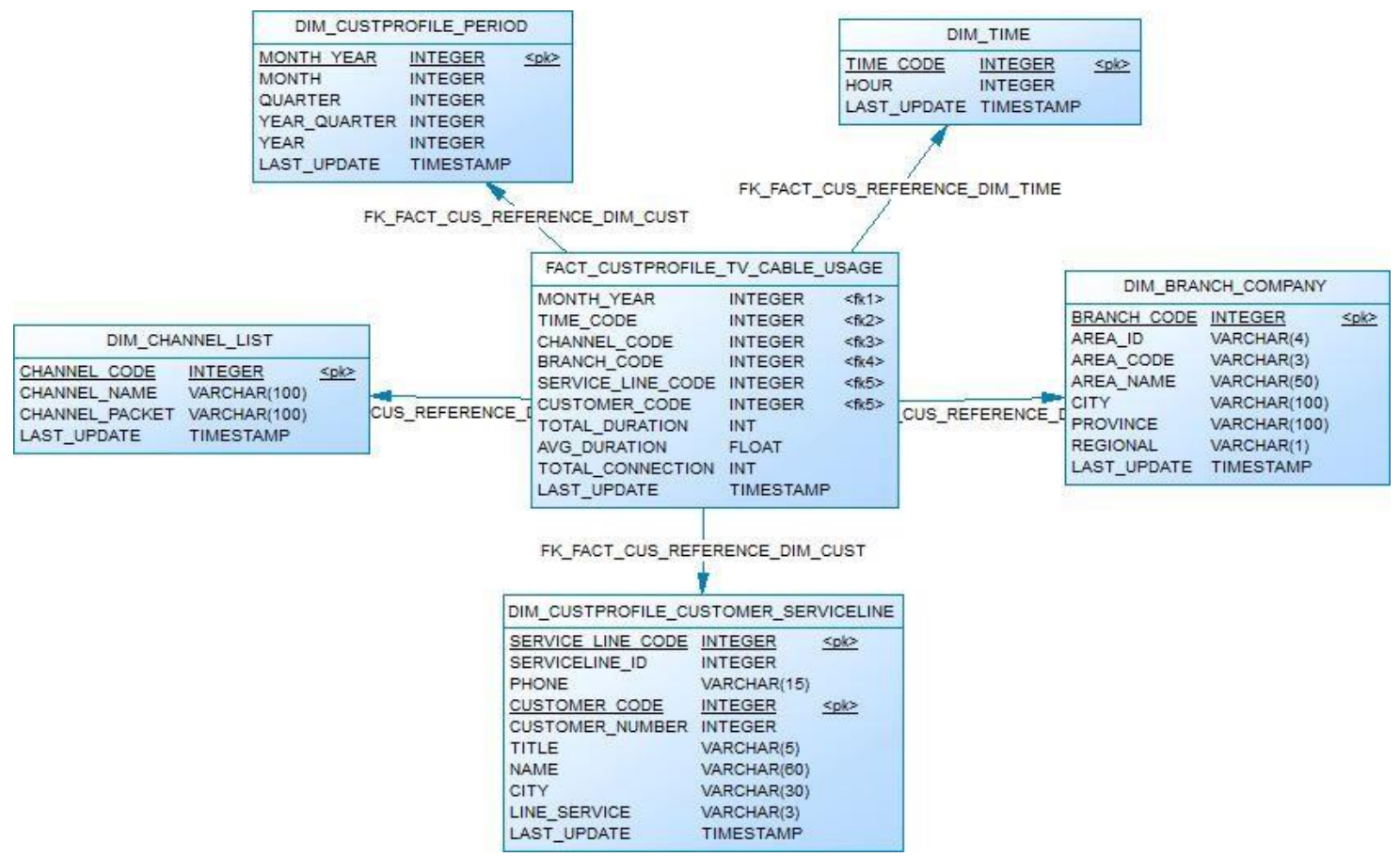

Gambar 8 Skema TV Cable Usage

\section{Skema Tagihan}

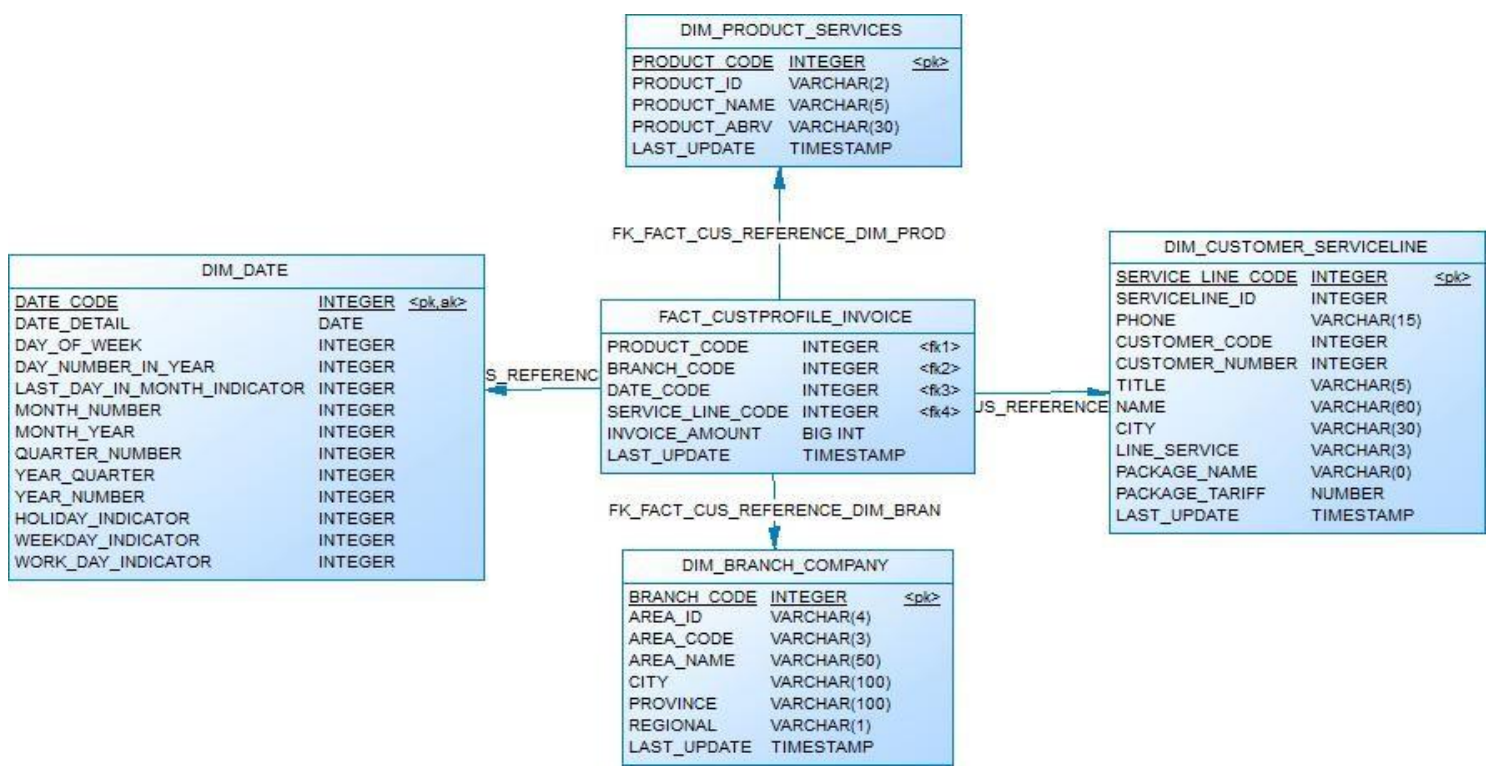

Gambar 9 Skema Invoice 


\section{Skema Pembayaran}

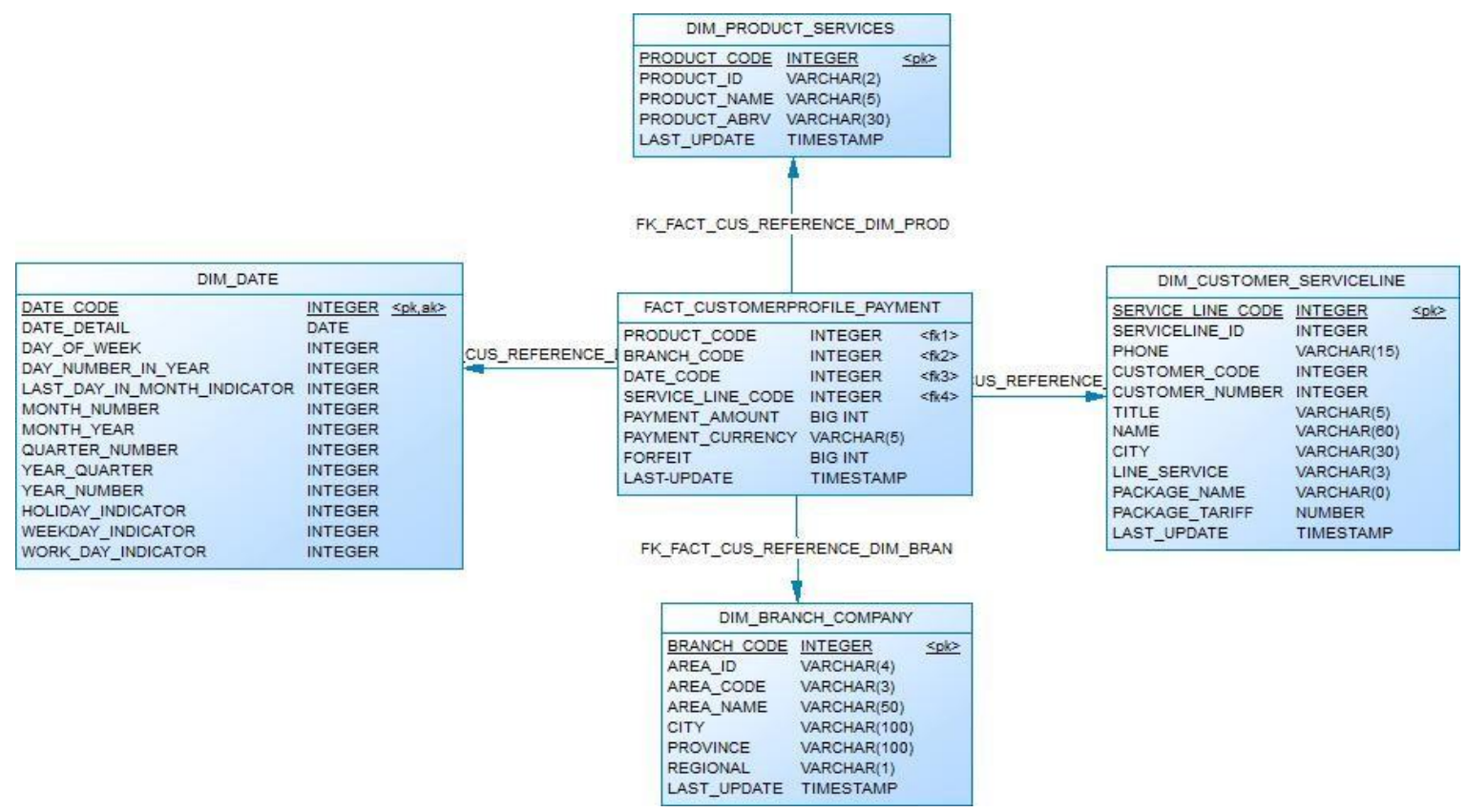

Gambar 10 Skema Payment

\section{Kesimpulan (Conclusion)}

Penerapan Business Intelligence (BI) seperti pada penelitian ini juga bisa diterapkan pada bidang yang lainnya dengan sedikit penyesuaian. Tahapan BI seperti pada penelitian ini dapat diterapkan pada setiap perusahaan yang mengelola pelanggan serta memiliki produk yang ditawarkan untuk pelanggannya. Misalnya diterapkan pada perusahaan retail yang juga mengelola pelanggan dan melakukan penjualan produk mereka.

BI dapat menyediakan informasi bagi perusahaan dalam melihat bisnisnya, pada penelitian ini khususnya dalam hal mengelola pelanggan. Metode yang digunakan penulis adalah data warehouse. Dengan data warehouse perusahaan dapat melihat historis perusahaan. Pendekatan yang diakai dalam membangun skema data warehouse adalah pendekatan Kimball karena pada studi kasus ini hanya melibatkan sebuah rangkaian proses bisnis yang diambil (tidak semua proses bisnis). Penerapan data warehouse akan sangat berguna bagi perusahaan dalam mengelola datanya.

Pada penelitian ini hanya mengambil satu rangkaian proses bisnis yang melibatkan data pemakaian layanan, tagihan, serta pembayaran. Untuk proses bisnis yang lain akan berbeda penanganannya. Untuk melakukan analisa lebih lanjut dapat dilakukan dengan menggunakan metode Business Intelligence lainnya, seperti data mining.

\section{Ucapan Terima Kasih (Acknowledgement)}

Penulis sangat berterima kasih kepada pihak Institut Teknologi Telkom Surabaya sebagai institusi yang mendukung penelitian yang dilakukan oleh penulis, serta semua pihak lainnya yang membantu penelitian ini.

\section{Daftar Pustaka}

Almeida, F. (2017). Concepts and Fundaments of Data Warehousing and OLAP.

Dageville, B. C. (2016). The snowflake elastic data warehouse. International Conference on Management of Data (pp. 215-226). ACM. 
Das, I. R. (2019). A Data Warehouse Based Schema Design on Decision-Making in Loan Disbursement for Indian Advance Sector. In Emerging Technologies in Data Mining and Information Security (IEMIS) (pp. 603-614). Singapore: Springer.

Farooqui, N. A. (2018). Design of A Data Warehouse for Medical Information System Using Data Mining Techniques. In 2018 Fifth International Conference on Parallel, Distributed and Grid Computing $(P D G C)$ (pp. 199-203). IEEE.

Gartner. (2015, 10 01). From Gartner IT Glossary: https://www.gartner.com/it-glossary/business-intelligencebi/

Hofer, I. S. (2016). A systematic approach to creation of a perioperative data warehouse. Anesthesia \& Analgesia, 1880-1884.

Inmon, W. H. (2005). Building the Data Warehouse, Fouth Edition. John Wiley and Sons, Inc.

Kimball, R. M. (2002). The Data Warehouse Toolkit, Second Edition:The Complete Guide to Dimensional Modelling. John Wiley and Sons, Inc.

Kimball, R. M. (2007). The Data Warehouse Lifecycle Toolkit, Second Edition. USA: Willey.

Nasrullah, M., Angresti, N. D., Suryawan, S. H., \& Mahananto, F. (2021). Requirement Engineering terhadap Virtual Team pada Proyek Software Engineering. Journal of Advances in Information and Industrial Technology, 1-10.

Suba, C. (2018). Data Warehousing Methods and its Application. International Journal of Engineering Science Invention (IJEsI), (pp. 12-19). 
JAIIT (Journal of Advances in Information and Industrial Technology) Vol. 3, No. 2 November 2021, ISSN 2723-4371, E-ISSN 2723-5912

Halaman ini sengaja dikosongkan 